\title{
Computed tomography (CT) intestinal alterations of Coronavirus Disease 2019 (COVID-19) from the imaging perspective: a case description
}

\author{
Lei Tang ${ }^{1 \#}$, Xinge Cheng ${ }^{2 \#}$, Chong Tian ${ }^{1}$, Rongpin Wang ${ }^{1}$, Hourong Zhou ${ }^{3}$, Weidong Wu ${ }^{4,5}$, Lin Yan $^{6}$, \\ Xianchun Zeng ${ }^{1,2}$ \\ ${ }^{1}$ Department of Radiology, Guizhou Provincial People's Hospital, Key Laboratory of Intelligent Medical Imaging Analysis and Accurate Diagnosis \\ of Guizhou Province, International Exemplary Cooperation Base of Precision Imaging for Diagnosis and Treatment, Guiyang 550002, China; \\ ${ }^{2}$ Department of Graduate School, Zunyi Medical University, Zunyi 563000, China; ${ }^{3}$ Department of General Practice, Guizhou Provincial People's \\ Hospital, Guiyang 550002, China; ${ }^{4}$ Guizhou Normal College, Guiyang 550002, China; ${ }^{5}$ Jiangjunshan Hospital of Guizhou Province, Guiyang \\ 550002, China; 'Department of Radiology, Changshun County People's Hospital, Changshun 550700, China
}

${ }^{\#}$ These authors contributed equally to this work.

Correspondence to: Xianchun Zeng. Guizhou Provincial People's Hospital, Zhongshan East Road 83, Guiyang 550002, China.

Email: zengxianchun04@foxmail.com.

Submitted Apr 01, 2020. Accepted for publication Apr 29, 2020.

doi: 10.21037/qims.2020.04.09

View this article at: http://dx.doi.org/10.21037/qims.2020.04.09

\section{Introduction}

In December 2019, a series of pneumonia cases with unknown etiology emerged in Wuhan, Hubei Province of China (1-3). They were later identified to be caused by Severe Acute Respiratory Syndrome Corona Virus 2 (SARS-CoV-2) (4). On February 11, 2020, the disease of pneumonia caused by the novel coronavirus was officially named Coronavirus Disease 2019 (COVID-19). By now, the outbreak of COVID-19 has spread rapidly to more than 150 countries worldwide. Epidemiological analysis of COVID-19 revealed that most confirmed cases initially developed fever and dry cough at the onset of illness, while very few showing gastrointestinal symptoms (5). Hereby, we report the clinical features as well as chest and abdominal CT findings of a case of COVID-19 infection confirmed in Jiangjunshan Hospital of Guizhou Province (a designated branch of Guiyang Public Health Center in Guiyang, Guizhou Province, for new coronavirus pneumonia treatment).

\section{Case presentation}

A 24-year-old man presented to the Changshun County
People's Hospital on February 5, 2020, with a 1-day history of abdominal pain and diarrhea (three times a day), mild cough, and running nose. He reported no previous history of chronic diarrhea or inflammatory bowel disease. $\mathrm{He}$ worked in Wuhan during the COVID-19 outbreak and had not been to the Huanan Seafood Market. Considering the epidemiological history, the patient was isolated immediately and received computed tomography (CT) and laboratory examinations. Blood test revealed leukopenia \{white blood cell count: $3.8 \times 10^{9} / \mathrm{L}$; normal range, $\left.[4-10] \times 10^{9} / \mathrm{L}\right\}$. The first unenhanced chest CT imaging (February 6, 2020) showed peripheral patchy ground-glass opacities in the left lung (Figure 1A). He was thus diagnosed with highly suspected COVID-19 and given Oseltamivir $(75 \mathrm{mg})$ and Norfloxacin $(0.3 \mathrm{~g})$ twice daily. Then, based on two real-time reverse-transcription polymerase chain reaction (rRT-PCR) assays on the oropharyngeal swab specimens, which were sampled on two consecutive days (February 7 and 8), and both showed positive, he was diagnosed with COVID-19 pneumonia. On February 10, the patient's diarrhea symptoms relieved, and a second CT scan revealed a reduction of left pulmonary lesions (Figure 1B). According to the suggestion of local Disease Control 

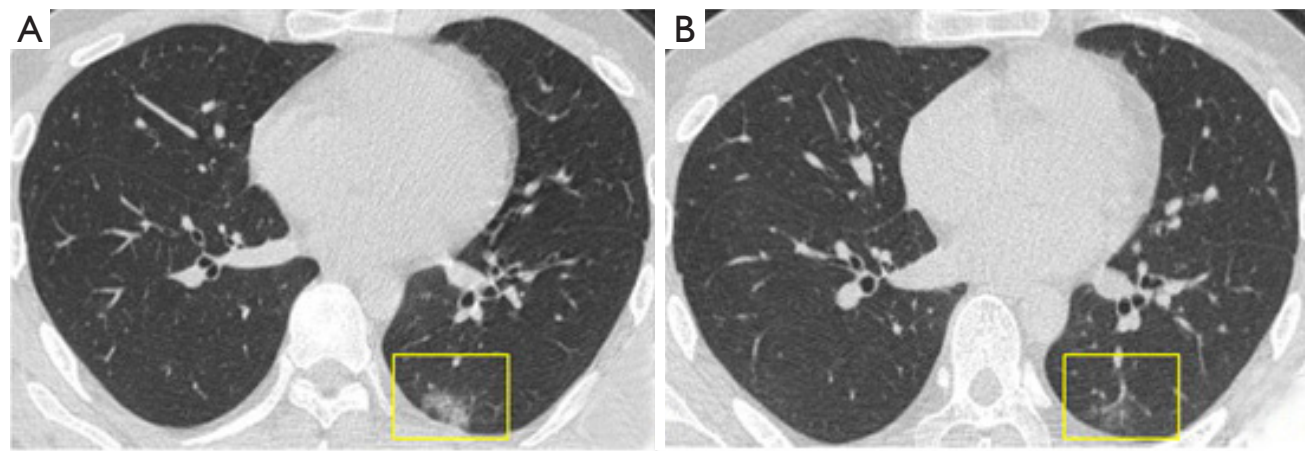

Figure 1 Unenhanced CT images of a 24-year-old COVID-19 patient. (A) The initial axial chest CT imaging (February 6, 2020) shows peripheral ground-glass opacities in the lower lobe of the left lung without consolidation (yellow frame); (B) the second chest CT (February 10, 2020) reveals reduced volume and density of the left pulmonary lesion (yellow frame).
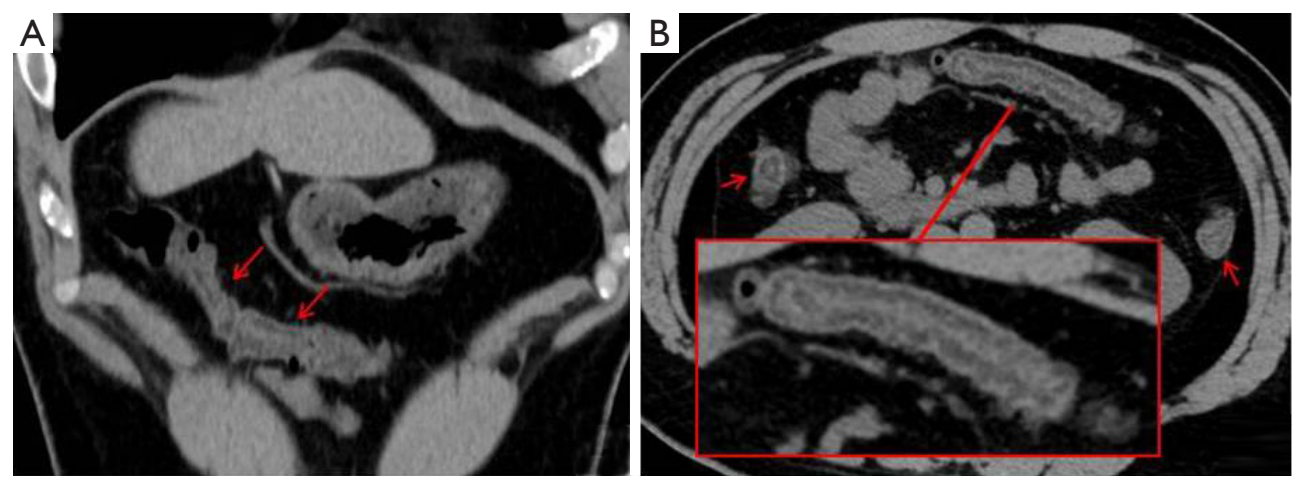

Figure 2 The third unenhanced CT images of the patient (February 12, 2020). The coronal (A) and axial (B) CT images of the abdomen reveal edema of intestinal wall in the distal ascending colon, transverse colon, and proximal colon in the descending colon (red arrows), with no exudation in the surrounding fat space. Magnification of the local image of the axial image (B, red frame) shows that the intestinal wall of the colon is swollen, layered, and the surrounding mesenteric vessels are slightly dilated. CT, computed tomography.

and Prevention Center (CDC), he was transferred to Jiangjunshan Hospital of Guizhou Province.

At admission (February 11), he had a body temperature of $36.4{ }^{\circ} \mathrm{C}$, blood pressure of $125 / 80 \mathrm{mmHg}$, pulse of $78 \mathrm{beats} / \mathrm{min}$, and a respiratory rate of 19 breaths/min. Both lungs had normal auscultation assessments, and oxygen saturation was $97 \%$ (when breathing ambient air). Blood count revealed normal results for leukocytes $\left(4.38 \times 10^{9} / \mathrm{L}\right)$, lymphocytes $\left(1.15 \times 10^{9} / \mathrm{L}\right)$, and neutrophils $\left(2.62 \times 10^{9} / \mathrm{L}\right)$. The patient had slightly increased $\mathrm{C}$-reactive protein (16 mmg/L; normal range, $<10 \mathrm{mmg} / \mathrm{L}$ ) and erythrocyte sedimentation rate $(24 \mathrm{~mm} / \mathrm{h}$; normal range, $<20 \mathrm{~mm} / \mathrm{h})$, and mild hypokalemia $(3.2 \mathrm{mmol} / \mathrm{L}$; normal range, $3.5-5.5 \mathrm{mmol} / \mathrm{L}$ ). Since the patient had dull pain in the upper abdomen, CT examinations (February 12, the third scan after onset) of the chest and upper abdomen were performed. Chest CT displayed small patchy groundglass opacities in the left lower lobe. Unenhanced upperabdomen $\mathrm{CT}$ revealed intestinal edema in the distal ascending colon, transverse colon, and proximal colon in the descending colon (Figure 2).

After 4 days of treatment with a combination of oral lopinavir/ritonavir $(200 \mathrm{mg} / 50 \mathrm{mg}, 2$ tablets at a time, once daily) and interferon (50 $\mu \mathrm{g}$, spray inhalation, twice daily), the patient's symptoms diminished. Follow-up chest and abdomen CT scans (February 16) showed decreased density of the ground-glass opacity in the left lower lobe, and the intestinal edema of colonic walls substantially disappeared (Figure 3). Subsequently, two sputum samples and one anal swab rRT-PCR test (sampling interval $>24$ h) showed 

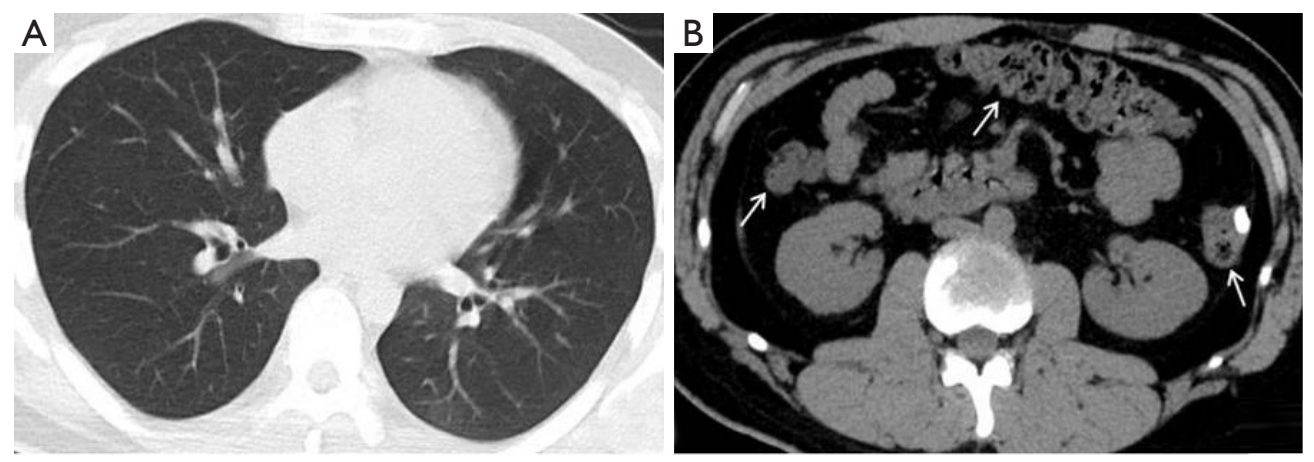

Figure 3 The fourth unenhanced CT images of the patient (February 16, 2020). (A) The ground-glass opacity in the lower lobe of the left lung is almost absorbed; (B) the edema of intestinal wall in the transverse colon, ascending colon, and descending colon substantially disappears, and the colon appears to normal (white arrows).

negative results for SARS-CoV-2 nucleic acid. The patient was therefore discharged.

\section{Discussion}

As of March 24, 2020, more than 372,757 cases of COVID-19 have been reported in more than 150 countries and regions, including 16,231 deaths, causing a worldwide pandemic (6). Compared to fever and cough that are common symptoms of COVID-19, diarrhea and other gastrointestinal symptoms are relatively rare (7-9). The case reported here was a young man with a clear epidemiological history, who complained gastrointestinal symptoms (diarrhea and abdominal pain) with mild respiratory problems. He was further diagnosed as COVID-19 by nucleic acid test.

The symptoms caused by SARS-CoV-2 infection in humans greatly resemble those by severe acute respiratory syndrome coronavirus (SARS-CoV). Complete genome sequencing found that SARS-CoV-2 shares $86.9 \%$ nucleotide sequence identity with severe acute respiratory syndrome-like coronavirus detected in bats (bat-SLCoVZC45, MG772933.1), indicating that SARS-CoV-2 belongs to the family of SARS-related coronavirus (SARSr-CoV) (10). The SARS-CoV-2 enters the cell using angiotensin converting enzyme II (ACE2) as its receptor, a similar mechanism as that of SARS-CoV infection (11). ACE2 is abundant in human pulmonary and intestinal epithelial cells. Previous studies have suggested that ACE2 is primarily expressed on the small intestinal epithelial cells on the lumen surface and less expressed in the colon (12). Recent bioinformatics analysis indicated that ACE2 is not only expressed in the lung cells, but also highly expressed in epithelial cells of esophagus, ileum, and colon (13). This theoretically explained why gastrointestinal symptoms are the main manifestation of some infected patients (14). Moreover, although SARS-CoV-2 nuclei acid has also been detected in the feces of confirmed patients, whether COVID-19 can be transmitted through the fecal-oral route remains controversial $(15,16)$.

Currently, there are few reports on intestinal pathological changes in COVID-19 patients. On February 16, 2020, Liu et al. performed an autopsy on an 85-year-old severe COVID-19 victim. Gross anatomy revealed slight effusion in the abdominal cavity, normal color of the intestinal tract, and dilatation and narrowing of segments of the small intestine (with beaded changes) (17). However, the authors were unsure whether the changes in the small intestine are atypical or a common manifestation of COVID-19, and more autopsy findings are required for confirmation. On the other hand, this patient we reported had no previous history of chronic diarrhea or inflammatory bowel disease, and he initially presented with digestive tract symptoms. Although abdominal CT examination was not performed at the time of onset (possibly due to insufficient attention), the colon-intestinal wall edema was shown from CT on day 7. After standard anti-COVID-19 treatment, the clinical symptoms were relieved, nucleic acid test turned negative, and follow-up CT showed that the intestinal wall edema of the colon disappeared. Therefore, it is reasonable that the CT findings of the intestinal tract are associated with COVID-19 infection.

According to the latest "Diagnosis and Treatment Plan of Novel Coronavirus Pneumonia" (7th edition), pathological 
manifestations of the stomach and intestines in COVID-19 mainly include different degrees of degeneration, necrosis and detachment of mucosal epithelium (18). The CT findings of the patient suggested that the intestinal walls of the ascending colon, transverse colon and descending colon are thickened, swollen and stratified (which resemble the changes of inflammatory bowel disease), which are basically consistent with the pathological results. Therefore, for confirmed COVID-19 patients with gastrointestinal symptoms, abdominal CT scan may provide more evidence for intestinal changes in the disease.

In conclusion, early identification and diagnosis of COVID-19 patients with atypical clinical manifestations is a great challenge for clinicians. If the epidemiological history is concealed or not investigated clearly, the COVID-19 patients who predominantly present with gastrointestinal symptoms (e.g., diarrhea and abdominal pain) may be easily misdiagnosed as common infectious diarrhea. Therefore, in the current pandemic situation of COVID-19, clinicians should be cautious to distinguish patients with gastrointestinal symptoms as the initial or primary manifestation.

\section{Acknowledgments}

Funding: This study was supported by Guizhou Science and Technology Project \{QKHZC[2020]4Y002\}, Guiyang Science and Technology Project $\{$ ZKXM[2020]4\}, and Guizhou Science and Technology Department Key Laboratory Project $\{\mathrm{QKF}[2017] 25\}$.

\section{Footnote}

Conflicts of Interest: All authors have completed the ICMJE uniform disclosure form (available at http://dx.doi.org/ 10.21037/qims.2020.04.09). All authors report grants from Guizhou Science and Technology Project, grants from Guizhou Science and Technology Department Key Lab Project, during the conduct of the study.

Informed Consent: Ethical approval was granted from the ethics committee of hospital, and written informed consent was obtained from the patient for publication of this manuscript and any accompanying images.

Open Access Statement: This is an Open Access article distributed in accordance with the Creative Commons Attribution-NonCommercial-NoDerivs 4.0 International
License (CC BY-NC-ND 4.0), which permits the noncommercial replication and distribution of the article with the strict proviso that no changes or edits are made and the original work is properly cited (including links to both the formal publication through the relevant DOI and the license). See: https://creativecommons.org/licenses/by-nc-nd/4.0/.

\section{References}

1. Li Q, Guan X, Wu P, Wang X, Zhou L, Tong Y, Ren R, Leung KSM, Lau EHY, Wong JY, Xing X, Xiang N, Wu Y, Li C, Chen Q, Li D, Liu T, Zhao J, Liu M, Tu W, Chen C, Jin L, Yang R, Wang Q, Zhou S, Wang R, Liu H, Luo Y, Liu Y, Shao G, Li H, Tao Z, Yang Y, Deng Z, Liu B, Ma Z, Zhang Y, Shi G, Lam TTY, Wu JT, Gao GF, Cowling BJ, Yang B, Leung GM, Feng Z. Early Transmission Dynamics in Wuhan, China, of Novel CoronavirusInfected Pneumonia. N Engl J Med 2020;382:1199-207.

2. Wu F, Zhao S, Yu B, Chen YM, Wang W, Song ZG, Hu Y, Tao ZW, Tian JH, Pei YY, Yuan ML, Zhang YL, Dai FH, Liu Y, Wang QM, Zheng JJ, Xu L, Holmes EC, Zhang $\mathrm{YZ}$. A new coronavirus associated with human respiratory disease in China. Nature 2020;579:265-9. Erratum in: Nature 2020;580:E7.

3. Huang C, Wang Y, Li X, Ren L, Zhao J, Hu Y, Zhang L, Fan G, Xu J, Gu X, Cheng Z, Yu T, Xia J, Wei Y, Wu W, Xie X, Yin W, Li H, Liu M, Xiao Y, Gao H, Guo L, Xie J, Wang G, Jiang R, Gao Z, Jin Q, Wang J, Cao B. Clinical features of patients infected with 2019 novel coronavirus in Wuhan, China. Lancet 2020;395:497-506. Erratum in: Department of Error. Lancet 2020;395:496.

4. Zhou P, Yang XL, Wang XG, Hu B, Zhang L, Zhang W, Si HR, Zhu Y, Li B, Huang CL, Chen HD, Chen J, Luo Y, Guo H, Jiang RD, Liu MQ, Chen Y, Shen XR, Wang X, Zheng XS, Zhao K, Chen QJ, Deng F, Liu LL, Yan B, Zhan FX, Wang YY, Xiao GF, Shi ZL. A pneumonia outbreak associated with a new coronavirus of probable bat origin. Nature 2020;579:270-3.

5. Guan WJ, Ni ZY, Hu Y, Liang WH, Ou CQ, He JX, Liu L, Shan H, Lei CL, Hui DSC, Du B, Li LJ, Zeng G, Yuen KY, Chen RC, Tang CL, Wang T, Chen PY, Xiang J, Li SY, Wang JL, Liang ZJ, Peng YX, Wei L, Liu Y, Hu YH, Peng P, Wang JM, Liu JY, Chen Z, Li G, Zheng ZJ, Qiu SQ, Luo J, Ye CJ, Zhu SY, Zhong NS; China Medical Treatment Expert Group for Covid-19. Clinical Characteristics of Coronavirus Disease 2019 in China. N Engl J Med 2020:NEJMoa2002032. [Epub ahead of print]. doi: 10.1056/NEJMoa2002032. 
6. World Health Organizatio (WHO). Novel Coronavirus (2019-nCoV) situation reports. Accessed March 4, 2020. Available online: https://www.who.int/emergencies/ diseases/novel-coronavir us-2019/situation-reports

7. Chen N, Zhou M, Dong X, Qu J, Gong F, Han Y, Qiu Y, Wang J, Liu Y, Wei Y, Xia J, Yu T, Zhang X, Zhang L. Epidemiological and clinical characteristics of 99 cases of 2019 novel coronavirus pneumonia in Wuhan, China: a descriptive study. Lancet 2020;395:507-13.

8. An P, Chen HB, Jiang XD, Su J, Xiao Y, Ding YJ, Ren HX, Ji MY, Chen YF, Chen W, Lv XG, Shen L, Chen MK, Li J, Yin AN, Kang J, Liu SZ, Tan W, Wu LL, Dong WG, Cao JW, Zhou ZY, Tan SY, Chen GZ, Zhou J, Yang YN, Yu HG. Clinical Features of 2019 Novel Coronavirus Pneumonia Presented Gastrointestinal Symptoms But Without Fever Onset. The lancet, 2020. Available online: https://ssrn.com/abstract=3532530

9. Zhou S, Wang Y, Zhu T, Xia L. CT Features of Coronavirus Disease 2019 (COVID-19) Pneumonia in 62 Patients in Wuhan, China. AJR Am J Roentgenol 2020. [Epub ahead of print]. doi: 10.2214/AJR.20.22975.

10. Lu R, Zhao X, Li J, Niu P, Yang B, Wu H, Wang W, Song H, Huang B, Zhu N, Bi Y, Ma X, Zhan F, Wang L, Hu T, Zhou H, Hu Z, Zhou W, Zhao L, Chen J, Meng Y, Wang J, Lin Y, Yuan J, Xie Z, Ma J, Liu WJ, Wang D, Xu W, Holmes EC, Gao GF, Wu G, Chen W, Shi W, Tan W. Genomic characterisation and epidemiology of 2019 novel coronavirus: implications for virus origins and receptor binding. Lancet 2020;395:565-74.

11. Wan Y, Shang J, Graham R, Baric RS, Li F. Receptor Recognition by the Novel Coronavirus from Wuhan: an Analysis Based on Decade-Long Structural Studies of SARS Coronavirus. J Virol 2020;94:e00127-20.

12. Hashimoto T, Perlot $T$, Rehman A, Trichereau J, Ishiguro H, Paolino M, Sigl V, Hanada T, Hanada R, Lipinski S, Wild B, Camargo SM, Singer D, Richter A, Kuba K,

Cite this article as: Tang $\mathrm{L}$, Cheng $\mathrm{X}$, Tian $\mathrm{C}$, Wang $\mathrm{R}$, Zhou H, Wu W, Yan L, Zeng X. Computed tomography (CT) intestinal alterations of Coronavirus Disease 2019 (COVID-19) from the imaging perspective: a case description. Quant Imaging Med Surg 2020;10(5):1145-1149. doi: 10.21037/ qims.2020.04.09
Fukamizu A, Schreiber S, Clevers H, Verrey F, Rosenstiel P, Penninger JM. ACE2 links amino acid malnutrition to microbial ecology and intestinal inflammation. Nature 2012;487:477-81.

13. Zhang H, Kang ZJ, Gong HY, Xu D, Wang J, Li ZF, Cui XG, Xiao JR, Meng T, Zhou W, Liu JM, $\mathrm{Xu} \mathrm{HJ}$. The digestive system is a potential route of 2019-nCov infection: a bioinformatics analysis based on single-cell transcriptomes. bioRxiv 2020. doi: 10.1101/2020.01.30.927806. [Epub ahead of print].

14. Song Y, Liu P, Shi XL, Chu YL, Zhang J, Xia J, Gao XZ, Qu T, Wang MY. SARS-CoV-2 induced diarrhoea as onset symptom in patient with COVID-19. Gut 2020. [Epub ahead of print]. doi: 10.1136/gutjnl-2020-320891.

15. Holshue ML, DeBolt C, Lindquist S, Lofy KH, Wiesman J, Bruce H, Spitters C, Ericson K, Wilkerson S, Tural A, Diaz G, Cohn A, Fox L, Patel A, Gerber SI, Kim L, Tong S, Lu X, Lindstrom S, Pallansch MA, Weldon WC, Biggs HM, Uyeki TM, Pillai SK; Washington State 2019-nCoV Case Investigation Team. First Case of 2019 Novel Coronavirus in the United States. N Engl J Med 2020;382:929-36.

16. National Health Commission of the People's Republic of China. What is fecal- oral transmission? Available online: http://www.nhc.gov.cn/xcs/nwwd/202002/f0ada96415be45 1a8863fbebde104a62.shtml

17. Liu Q, Wang RS, Qu GQ, Wang YY, Liu P, Zhu YZ, Fei G, Ren L, Zhou YW, Liu L. A report on the general observation of the necropsy of the novel coronavirus pneumonia (in Chinese). Fa Yi Xue Za Zhi 2020. doi: 10.12116/j.issn.1004-5619.2020.01.005

18. National Health Commission of the People's Republic China: The diagnosis and treatment guidelines of COVID-19 (7th edition). Accessed March 4, 2020. Available online: http://www.nhc.gov.cn/yzygj/s7653p/202 003/46c9294a7dfe4cef80dc7f5912eb1989.shtml 